\title{
Harmonize The Interior Retail Space in Era Post Covid-19, Study Case The Element Of Servicescape In Jakarta Mall
}

\author{
Ulli Aulia Ruki ${ }^{1 *}$ \\ ${ }^{1}$ Interior Design Department, School of Design, Bina Nusantara University, Indonesia, \\ ${ }^{*}$ Corresponding author. Email: uruki@binus.edu
}

\begin{abstract}
Indonesia's retail industry, particularly Jakarta, has been oversupplied by building malls: some interior malls have repeatedly sold identical goods with the same brand and lacked service. Moreover, because the retail industry has other ways to sell during the pandemic, their e-commerce has become widespread, supported by internet access to remote areas. Some retail industries prefer to close their shops in malls and switch to selling online. To help this industry survive, malls need to adopt new services into their spaces to influence customer perceptions with understanding the servicescape positively.
\end{abstract}

In this study, perception maps were used to describe and develop new initiatives and were implemented due to customer perceptions; servicescape has changed in the new normal situation. Therefore, facility managers and interior designers need to understand the impact of the servicescape on the customer. The main objective of this study is to provide an overview of the servicescape concept, and the relevance of customer perception issues based on shopping centers in Jakarta, Indonesia. Theoretically, servicescape was first proposed by Mary Jo Bitner. she has shown the three elements of the environmental dimension that can influence customer perceptions; In this case, it is necessary to update the environmental situation during the post-covid-19 pandemic.

In this study, the Service Quality Gap Model is used to understand the position and perception map of the Servicescape Elements in providing additional insight to maintain service quality in interior retail space. In addition, servicescape elements need to be aligned with the current new normality protocol in the post-covid-19 and perceptual era. The map is used to manage the perception of consumer expectations and to translate the perception into the quality of service that the mall management will provide. This research ends with recommendations for shopping centres to provide standardization of facility operations to increase customer perceptions of being satisfied and potentially loyal customers.

Keywords: Retail Industry, Servicescape Elements, Interior Retail Space

\section{INTRODUCTION}

Since the beginning of the COVID-19 outbreak, some retail businesses have struggled to survive, and this news is almost universally heard in the media worldwide. Significantly, retailers have turned to online and other selling alternatives to reduce operational costs [1]. In addition, more than half of the department stores within building malls are predicted to be closed even in America's malls will be permanently closed due to bankruptcy of tenants [2]. A similar situation in Jabodetabek estimates an output economic loss of $15.2 \%$ during the pandemic and due to the conditions of Large-Scale Social Restrictions
(PSBB) that impact micro, small and medium enterprises or MSMEs [3].

According to the Association Survey (APJ), which provides a survey, it is stated that the majority of respondents, nearly 197 million Indonesians, actively use the internet to access social media, chat applications, banking, entertainment, and online shopping [4]. One of the changes reasons many stores are closing is due to the increasing prevalence of online shopping. Since Indonesian people actively use the internet, online shopping behaviour has also increased, customer experience in shopping has shifted to a digital experience 
Will shopping shift to digital experiences, and will shopping malls remain a marketplace, or will social media be a marketplace; Is there still room for visual appeal that can entice shoppers to shop on the spot. The relationship between interior design and servicescape in Jakarta malls: Interior retail space connected to the customer interest in on-site shopping. Unfortunately, the current conditions have changed due to the transmission of the covid 19 virus; customers must stay at home, limit their activities outside, and adopt safer behaviour during the lockdown in their city. Servicescape for several areas of marketing has become public information and is often used as a strategy to attract consumers [5]. The function of the servicescape itself, as mentioned by Bitner, should be to build an environment that is balanced or in line with the main purpose of a facility in the building. The first thing that Servicescape develops is an environment that can appear comfortable for customers while avoiding an atmosphere that creates a feeling of pressure. After that, Servicescape can manage the facility environment efficiently and simplify operating costs. In addition, the servicescape concept should emphasize the impact of the physical environment as part of the service process that takes the position. Consequently, the servicescape attributes need to be updated when re-opening a retail store.

The first element that needs to be updated is the spatial layout and function (SLF), which consists of furnishing, layout, and equipment. The second element is signs, symbols, and artifacts (SSA); the attributes are a style of décor, signage, and personal artifacts. The last element of servicescape is the ambient condition (AC) which involves of music, temperature, air quality, noise, and odour [6]. Those elements need to be updated at interior mall and responsive to new normal activities. In this pandemic period, customers may prefer to consider the level of comfort in visiting Jakarta malls by seeing how mall management adjusts implement safety protocols in shopping activities. Customer expectations are about the quality of cleanliness and hygiene within the facility

\subsection{Interior Mall Jakarta and Element Servicescape Spatial Layout and functionality (SLF) during a pandemic}

This SLF is the first important dimension because spatial planning refers to how devices, equipment and furniture are arranged, the spatial relationship between them, the choice of size and shape of these items can also affect the dimensions of spacing and layout.
For functionality refers to the ability to provide to meet customer expectations. The layout of the facilities is also important to consider, especially in the retail layout of a shopping centre building; This dimension affects customer satisfaction, store performance, and consumer behaviour in looking for something in the store [7]. Examples of SLF changes are in front of the mall entrance area, with the application of the new normal protocol; customers need to take several other steps before entering, such as disinfecting or washing hands with water and soap, then performing a temperature checking procedure, see figure 1

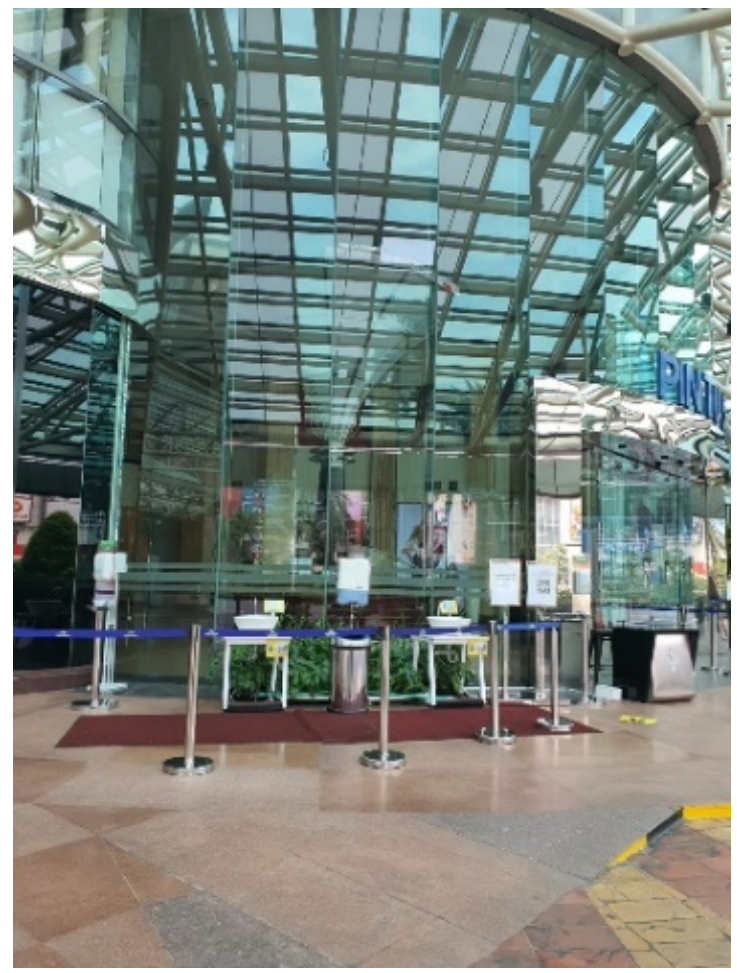

Figure 1. Example of element Servicescape Spatial Layout Function during pandemic

\subsection{Interior Mall Jakarta and Element Servicescape Signs, symbols, and artifact (SSA) during a pandemic}

The SSA is the second dimension for communicating new service concepts; when customers are unfamiliar with the service setting, they will look to environmental cues to help them categorize the premises and begin to form their quality expectations [8|. Symbols and artefacts can include less direct communication than signs. It implicitly signifies a place's meaning, norms, and user expectations for behaviour by attaching a photo, certificate, or work of art. 


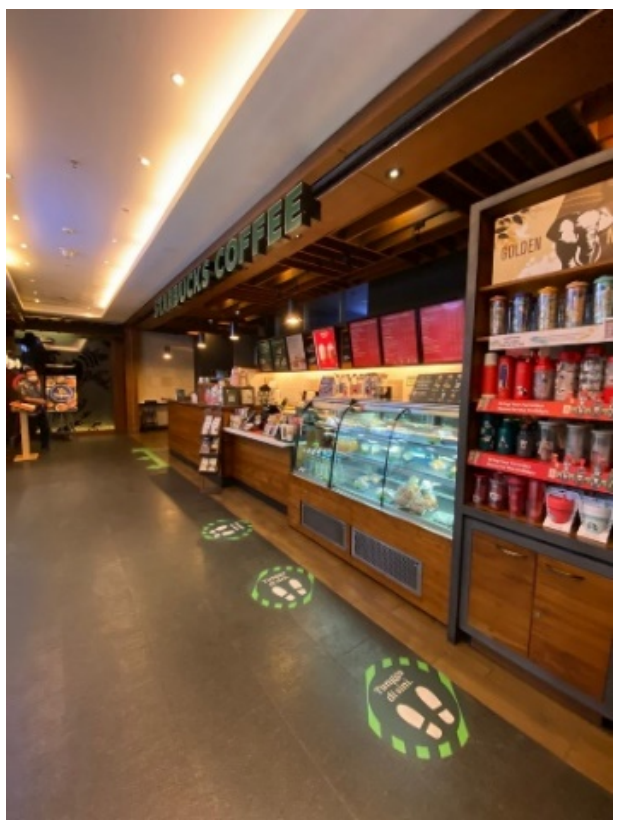

Figure 2. Example of element Servicescape Sign Symbols Artifact during pandemic

A sign is an element that refers to explicit communication to users within the facility. A sign can be displayed inside or outside the shop; Usually, when a sign becomes part of a store interior, it will provide directions to explain the space. For example, from the figure 2 customers need to queue and are expected to keep their distance from other customers.

\subsection{Interior Mall Jakarta and Element Servicescape Ambient Condition (AC) during pandemic}

The aspects of air conditioning can greatly influence how people fall, think, and respond to service; These elements include environmental background characteristics such as temperature, lighting, noise, music, and colour. Zeithaml \& Bitner's research shows that shopping without music playing in stores affects shoppers and spends less time than when there is music in stores. In addition, the slower tempo of the music makes the buyer more relaxed and relaxed. Thus, music will help customers feel relaxed and not feel the store is empty.

In figure 3 Customers are fully protected by wearing face shields and masks and visible boundaries in the room to limit customer movement and maintain distance to minimize the risk or transmission of the virus. Therefore, improving the quality of room temperature is important to upgrade during the pandemic.

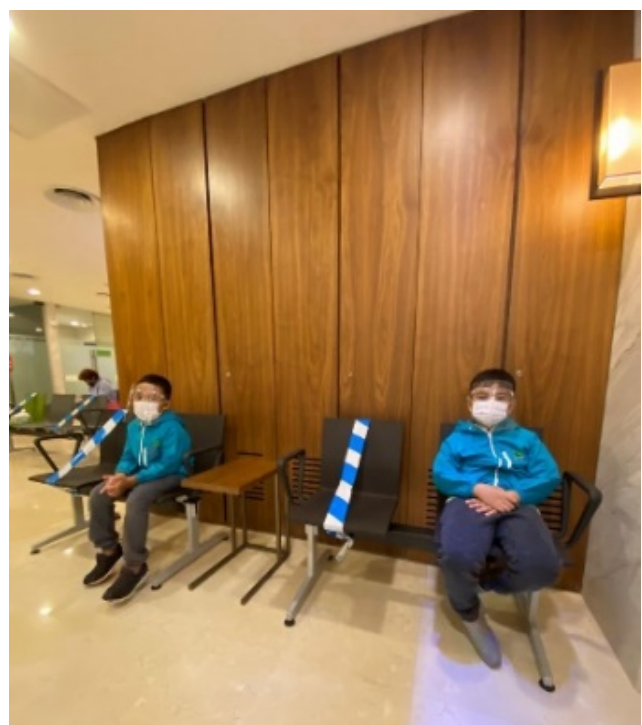

Figure 3. Example of element Servicescape Ambient Condition during pandemic

\subsection{Servicescape framework after pandemic}

Several servicescape studies have shown its effect on perceived service quality and specified internal responses to customers [7]. Some are influenced by cognition, emotion, physiology, and lastly, are variations in individual responses. Before the pandemic, Figure 4 The grey boxes are attributes of a normal servicecape; they describe a servicescape framework that shows the holistic and responsiveness of customers internally and their behaviour towards environmental dimensions. However, after the new normal situation, a coloured box appears that describes the most needed attributes to pay more attention to achieving customer expectations.

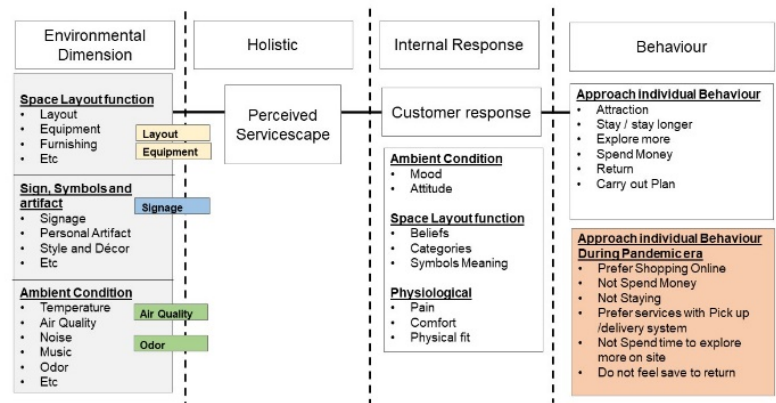

Figure 4 Servicescape framework before and after pandemic era (Adapted from Bitner 1992)

However, during this pandemic, the most significant changes in the attitude of responding to the environment that is felt from the cognitive are in the elements of layout, equipment, signage, air quality, odour. Mall visitors finally adapt and undergo the new normal protocols before entering the mall interior. In 
addition, while in the interior of the retail space, customers need to wear masks. This protocol is an example of environmental perceptions that affect the emotions of mall visitors who feel uncomfortable. In addition, the feeling of discomfort due to a crowded room and when the building manager does not apply health protocols. In the end, it disturbs the physiology of visitors who may decide not to shop at the location because they think it is unsafe to come to the mall because an unhealthy mall environment threatens it. This perceived response may differ from one visitor to another.

\section{PERCEPUAL MAP \& THE ELEMENT OF SERVICESCAPE}

After seeing the results of this survey, the results from here can provide an idea for designers and facility management on how to capture customer perceptions of what needs to be done post-pandemic. In his research, the GAP model analysis describes how the quality-of-service performance is provided and then delivered by the facility management and designer to meet the customer's perception of the services.The Service Quality Gap Model by Zeitham, Pasuraman, and Berry compares service quality performance with customer service quality needs and GAP can also be analyzed using a 5-component service quality approach: real, reliable, responsive, assurance, and empathetic [8].

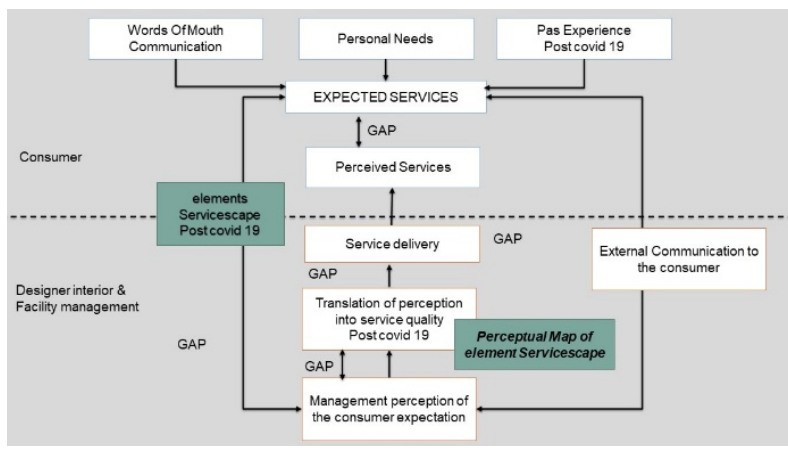

Figure 5. Position of element Servicescape \& perceptual map on Gap model of services quality (Adapted from Zeitham, Pasuraman, and Berry)

However, this current research will not focus on service quality analysis; it emphasizes tangible components, especially physical facilities. An analysis element such as the servicescape approach, the tangible component and the perceptual map approach will clarify designers collaborating with facility managers on improving facilities in shopping centres to bridge the customer expectations for the improvement or service that will be prepared.
Customers perspective towards elements of servicescape during pandemic in online shopping in this pandemic era, almost $90 \%$ said they order food online, delivery, or pick up services to avoid eating at restaurants. However, when shopping for clots and other accessories, around $40 \%$ choose to shop onsite, and $60 \%$ still prefer to shop online during a pandemic. It is almost the same with grocery shopping, namely $40 \%$ choose to shop online, and $40 \%$ shop onsite, the remaining $10 \%$ decide to use pick up or take away services.

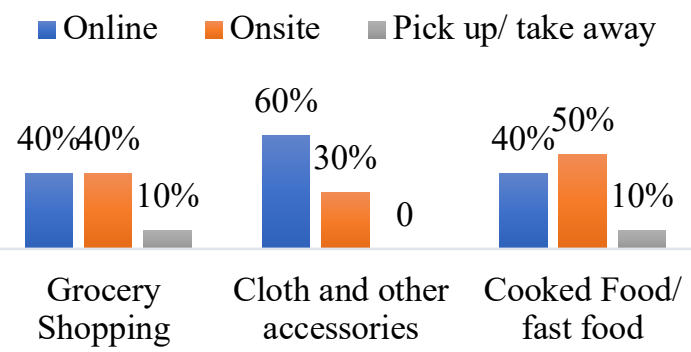

Figure 6. Shopping onsite or online

As can be seen from Figure 6, changes in shopping behaviour generally occur in each shopping category. Customers during the pandemic are reducing on-site shopping, but this condition is predicted to be temporary. Sellers during the pandemic facilitate onsite shopping and gradually because customers will also feel bored with routines and digital experiences, so they want to return to the on-site shopping experience. Therefore, mall managers need to prepare their facilities to win back customers' trust, showing that the environment around the mall is safe for shopping on the spot.

The data are collectively presented in Figure 7, which has been distributed in focus groups on women with a mean age of $30-50$, which shows $88.9 \%$ prefer visiting malls with good air circulation and prefer malls with open spaces. For $77.8 \%$ stated that they strongly agree to choose malls that have implemented physical distancing protocols. The application protocol for hand washing and the application of temperature checks before entering the mall and disinfectants were also an important part of participants' approval for $100 \%$. In addition, reservation services to limit space occupancy have also been $100 \%$ approved to be implemented in interior retail spaces. 


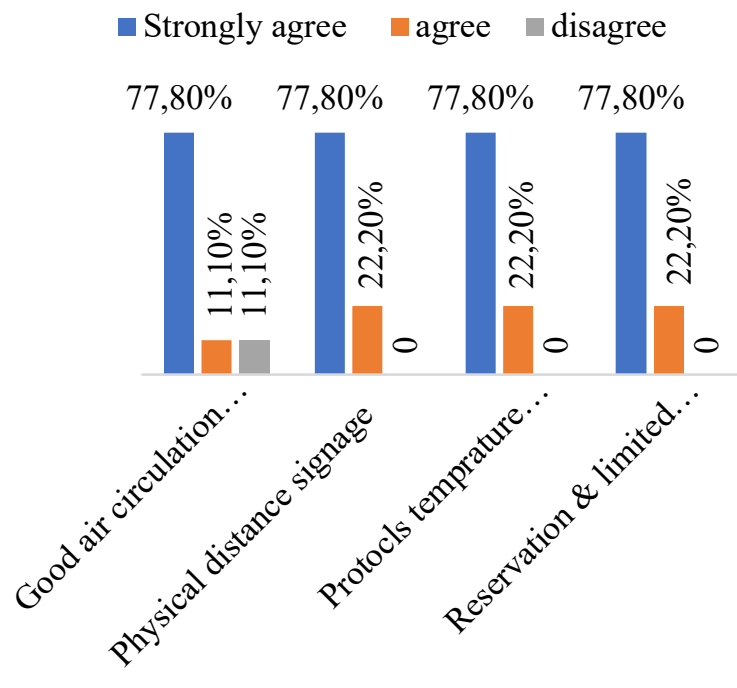

Figure 7. Interior retail space with New Normal protocol

These criteria such as good air circulation, openair system is mentioned by WHO's considerations on ventilation and air conditioning in public spaces and buildings. I note that on the roadmap ventilation is complementary; the main attention is devoted to the consultation and evaluation of their building's HVAC with professionals in terms of changing it [10]. For physical distancing, signage is intended to make a visual delivery method effective in reducing virus transmission and its practical principle is to create positive behavior change by graphically attracting customer attention [11].

\section{Perceptual Map of element Servicescape}

Perceptual mapping is a method that makes a map of people's perception is comparing alternatives [9]. The benefits of using these methods are to gain a competitive advantage and build a competitive strategy. Besides, it helps identify the potential new product/services, and help builds the customers expectation.

Using this method, the researcher tries to interpret the servicescape elements, namely SLF, SSA, and CA, to describe the possibility that can be improved performance to be assessed. The potential of new initiative about the new normal protocols; will be the focus that needs to be enhanced during the reopening of the mall after several months of lockdown; building management has applied the new normal protocols to be harmonized with the current condition and situation.

In addition, this perceptual is also inseparable from the positioning map, where this map provides zoning to know attributes positioning. Zone 1. (Tradition high cost) wherein this zoning area, the considered traditional, and every mall applied the attributes although the cost is relatively high. The second zonation is zone 2 (Traditional - Low cost) where the servicescape attributes in this zone use a low operational cost, and the standard furnishing. Next is zone 3 (Non-traditional - High cost) this zone explains that the attributes here are high innovated but can be done if the equipment is available on the market and the management building has the extra budget to implemented in pursuing the goal. The last zone 4 (Non-traditional - low-cost) in this zone, the attributes have a newness innovation and can potentially to be purchased because it uses a low operational cost.

In the figure 8 , it is explained that there are three elements of the servicescape such as layout and function (SLF) in the yellow group, symbols, signs \& artifacts (SSA) in the blue group, and Ambient condition (AC) in the green group.

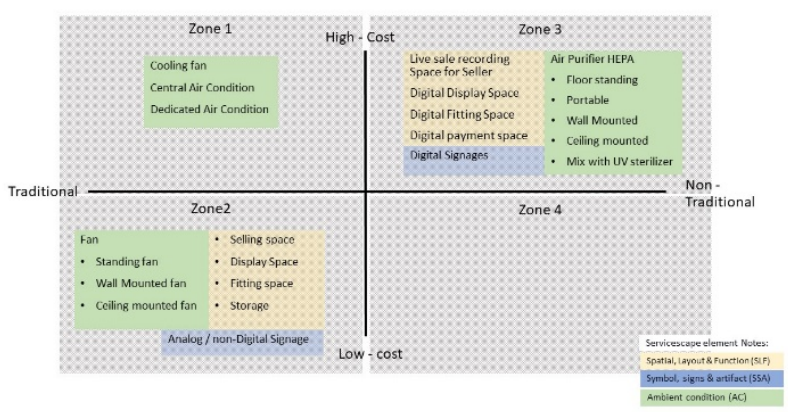

Figure 8. perceptual Map of element Servicescape post covid-19 era

Some layout and function zoning strategies for SLFs located in traditional and low-cost zones are still commonly used in some interior retail spaces. Meanwhile, in terms of high cost - non-traditional, SLF can be transferred by upgrading its technology and furnished with equipment in a digital platform. For SSA in traditional zones, the low-cost signage now available in the market is non-digital signage, while for high-cost non-traditional areas, the signage has turned digital

The last is the Ambient Condition (AC) element which is colored green in the image; for this pandemic period, it is urgent to provide a healthier and more hygienic atmosphere. For the current situation, fans or coolers are now commonly used in malls, as described in zones 1 and 2. However, for the Ambient Condition in zone 3, the main improvement proposed to the management building is to provide a healthier water flow with a HEPA Air Purifier (High-Efficiency 
Particulate Air Filter). According to a recent study conducted at a Clinic Healthcare facility, on average, air purifiers with filter media remove $54 \%$ of aerosols that may be carrying SARS-CoV-2 from the air. In comparison, high-grade filter media can remove $83 \%$ of aerosols. thus, air purifiers with HEPA may be more effective and protective than air purifiers with only fine filters [12].

\section{CONCLUSION}

In short, it is necessary to harmonize the interior of the retail space; whether a store will decide its service is done by shopping online or by shopping on the spot. In the end, the store can also appear as a hybrid store with a blended system where it can still run on-site and online services. This hybrid store system is still needed to match space requirements and collaborative thinking on applying new technology into the retail space.

From the perceptual map analysis results, initiatives in zones 3 and 4 require a long-term investment perspective. However, because all possibilities for upgrading are still very expensive and the technology is relatively rare, the preparation of the procurement proposal must have started. The Indonesian retail industry needs to create a strategy to align its customer's expected services with the new digital transformation and adapt to the new normal environment.

In addition, it is also necessary for an interior designer or retail industry to align future developments with design applications related to servicescape elements. This research will continue to link the servicescape elements that might influence consumer behavior in the shopping experience both digitally and on-site. This research is still limited and can be continued regarding whether technology will rebuild customer shopping behavior on the spot. Furthermore, need additional research related to the form of hybrid servicescape elements that can be done digitally and non-digitally.

\section{REFERENCES}

[1] A. Thapa, Retailers Are Shutting Down Physical Stores to Focus on Digital Sales. Retrieved from Thestreet.com: 2020 [cited 2021 march] avaliable from: https://www.thestreet.com/video/retailersshutting-down-physical-stores-focus-digitalsales
[2] L. Thomas, Over $50 \%$ of department stores in malls predicted to close by 2021 , real estate services firm says. Retrieved from CNBC: 2020 [cited 2021 January] avaliable from: https:/www.cnbc.com/2020/04/29/50percentof-all-these-malls-forecast-to-close-by-2021green-street-advisors-says.html

[3] T. Marchelin, Jakarta Globe Business. Retrieved from Jakarta Globe : 2020 [cited 2021 january] avaliable from: https://jakartaglobe.id/business/greater-jakartafaces-152-output-loss-from-pandemiceconomist

[4] Herman. Indonesia Has 197 Million Internet Users in 2020, APJII Survey Shows. Retrieved from Jakarta Globe: 2020, november [cited 2021 January] avaliable from: https://jakartaglobe.id/tech/indonesia-has-197million-internet-users-in-2020-apjii-surveyshows

[5] B. Figueiredo, H.P. Larsen, J. Bean, The Cosmopolitan Sercvicescape, in : Journal of Retailing, vol. 97(2), pp.267-287, 2021.

[6] M.J. Bitner, Servicescape : The Impact of Physical Surrounding on Customers and Employees, in : Journal of Marketing, vol.56(2), pp.57-71, 1992.

[7] K.L. Wakefield, J. Blodgett, The Effect of The Servicescape on Customers' Behavioral Intentions in Leisure Service Settings, in: Journal of Services Marketing, vol.10(6), pp.4561, 1996.

[8] K. Ravichandran, et al., Influence of Service Quality on Customer Satisfaction Application of Servqual Model, in : International Journal of Business and Management, vol. 5(4), April 2010.

[9] R. Curadale, Design Thinking Process and Methods Manual. Topanga CA : Design community colage Inc. 2013.

[10] World Health Organization, Roadmap to improve and ensure. Retrieved from Coronavirus disease (COVID-19): Ventilation and air conditioning in public spaces and buildings, 2020 [cited 2021 June] avaliable from: https:/www.who.int/news-room/q-adetail/coronavirus-disease-covid-19-ventilationand-air-conditioning-in-public-spaces-andbuildings 
[11] Group, A. I., COVID-19 Design Toolkit. Retrieved from COVID-19 Design Toolkit: 2020 [cited 2021 June] avaliable from: https://www.covid19designtoolkit.com/

[12] B. Zhao, N. An, C. Chen, Using an Air Purifier as a Supplementary Protective Measure in Dental Clinics During the Coronavirus Disease 2019 (COVID-19) Pandemic, in : Infection Control \& Hospital Epidemiology, vol. 42(4), p. 493, April 2021. doi:10.1017/ice.2020.292 